\title{
Effect of different processing methods on the chemical, functional and microbial properties of Mucuna sloanei seeds (Ukpo)
}

\author{
Obiakor-Okeke Philomena Ngozi ${ }^{1}$, Chikwendu Justina Ndirika ${ }^{2}$, Anozie Tochukwu ${ }^{1}$ \\ ${ }^{1}$ Faculty of Health Sciences, Department of Nutrition and Dietetics, Imo State University Owerri, Nigeria \\ ${ }^{2}$ Department of Home Science, Nutrition and Dietetics, University of Nigeria, Nsukka, Nigeria
}

Email address:

ngoziobiakor2001@yahoo.com (Obiakor-Okeke P. N.)

To cite this article:

Obiakor-Okeke Philomena Ngozi, Chikwendu Justina Ndirika, Anozie Tochukwu. Effect of Different Processing Methods on the Chemical, Functional and Microbial Properties of Mucuna sloanei Seeds (Ukpo). International Journal of Nutrition and Food Sciences.

Vol. 3, No. 6, 2014, pp. 551-559. doi: 10.11648/j.ijnfs.20140306.20

\begin{abstract}
The effect of fermentation, cooking and dehulling on the chemical properties (proximate, mineral and antinutritional factor), functional properties (least gelation concentration, bulk density, and water and oil absorption capacity) and microbial quality (the occurrence of micro-organism) in Mucuna sloanei seeds (Ukpo) were assessed. Official methods of Analysis was employed to analyze the samples. The result showed that fermentation increased the protein content from $24.0 \%$ (Dehulled) to $35.2 \%$ (72 hours fermentation). It also increased the mineral availability, created favourable condition for the growth of yeast, reduced the level of antinutrients and also reduced the water and oil absorption capacity. Cooking increase the carbohydrate content, improve the functional properties, decrease the anti-nutritional content but molds (Aspergillus $s p$ and Rhizopus sp) were isolated from it. Dehulling (raw) did not completely support gelation but can be regarded as a safe method of processing because it contains no microorganism. The study has assessed the different processing methods on the chemical, functional and microbial qualities of Mucuna sloanei. Fermentation was discovered to be the method that encouraged improved nutritional qualities however, other methods like dehulling are also very necessary to access the full nutritional potentials of Mucuna slonei.
\end{abstract}

Keywords: Processing Method, Chemical, Functional, Microbial, Properties, Mucuna sloanei Seeds

\section{Introduction}

Mucuna is a genus of around one hundred (100) accepted species of climbing vines and shrubs of the family fabaceae, found worldwide in the wood lands of tropical areas ${ }^{(1)}$. The leaves are 3-palmate, alternate or spiral and the lowers are pea-like but larger with distractive curved petals and occurring in racemes. Like other legumes, Mucuna plants bear pods. The seed pods are covered with microscopic velvety hairs (called trichomes) that can be extremely painful if they get into your eyes or could course itchy blister when they come in contact with skin. There are generally bat pollinated and produce seeds that are buoyant sea beans. These have a characteristics three-layered appearance, appearing like the eyes of a large mammal in some species and like a hamburger in others (most notably Mucuna sloanei) and giving rise to common names like deer eye beans, ox-eye beans or hamburger seed. Most species of Mucuna are climbing woody vines called lianas that twine through the rain forest like "botanical boa constructors". Pods are produced on long, rope-like stems that hand from the forest canopy. In the Caribbean region and Central America, the hairs were stirred into honey or syrup as a remedy to dispel intestinal parasites ${ }^{(2)}$. The dense covering of irritating hairs may help to discourage seed predators, particularly when the seeds are soft and vulnerable. At maturity, each pod produces several hard, marble like seeds. The closely related genus Dioclea includes woody vines which also produce seeds called sea beans. The pods of Dioclea generally do not have the stinging trichomes. The seeds of both genera are commonly polished and made into seed necklaces ${ }^{(3)}$.

Mucuna seeds are usually toasted for 5-10 minutes before grinding and flouring to supplement as thickener in sauce or soup. Mucuna sloanei is used by the Igbo community in Sub-Sahara Africa as condiment or part of the 
main dish ${ }^{(4-5)}$. Seeds of Mucuna sloanei popularly called Ukpo are used as thickener of soup and vegetable oil, beverages and food items ${ }^{(2,6)}$. Its seeds are cracked by hitting with a hard object before cooking, then dehulled, ground, mixed with red oil palm to obtain yellow powder and marketed as soup thickener ${ }^{(7)}$. After draining the cooking water, softened sees are dehulled, ground into paste and mixed with other ingredients e.g. chillies, eggplant, onions, meat or fish to prepare soup which is eaten along with starchy staples.

A black dye is obtained from all parts of Mucuna sloanei, which is used in Nigeria to dye fibre and leather back ${ }^{(4)}$. Cooked young fruits are eaten as a vegetable, in Nigeria Mucuna sloanei is occasionally cultivated for that purpose. The ripe seeds is eaten pounded and cooked preferably in soups. All parts of Mucuna plant are reported to possess phytochemicals of high medicinal value of human and veterinary importance and also constitute as an important raw material in Ayurvedic and folk medicines. Mucuna seeds constitute as a good source of several alkaloids, antioxidants, anti-tumor and anti-bacterial compounds. Seeds are the major source of L-DOPA, which serve as a potential drug in providing symptomatic relief for Parkinson's disease ${ }^{(8)}$.

Mucuna sloanei seeds consist of high protein, high carbohydrates, high fiber, low lipids, and adequate minerals and meet the requirement of essential amino acids. Hydrothermal treatments, fermentation and germination have been shown to be most effective in reducing the anti-nutrients of the seeds. Several anti-nutritional compounds of the seeds serve in health care and considerable has been drawn toward their antioxidant properties and potential health benefits ${ }^{(9)}$. It has nutritional potential as a rich source of protein $(23-35 \%){ }^{(1)}$.

Mucuna is used as a minor food crop in several countries of Asia and Africa ${ }^{(10)}$. Owing to its high protein content, it could be used to supplement cocoyam, which is a high carbohydrate soup thickener and melon which has high oil content. These soups thickeners could increase the caloric content of soup, thereby increasing the risk of weight gain. Protein energy deficiency has been recognized as the most common form of malnutrition in regions where people depend mainly on starch based diets ${ }^{(11-13)}$. Incorporation of this underutilized legume which is inexpensive and which meets the requirement of essential amino acids into the diet will no doubt improve the nutritional status and help reduce malnutrition. Its low lipid content (about 7\%), high fiber content about $9.6 \%$, and its high concentration of polyunsaturated fatty acid adds to its nutritional potential and increases the benefits derived on consumption.

Besides typical medicinal properties, several antinutritional compounds of Mucuna seeds serve in health care in a variety of ways. The phytic acid of Mucuna sloanei possess antioxidant, anti-carcinogenic and hypoglycemic activities $(14-15)$ and are effective at low concentrations. Saponins are recently shown to have hypocholestrolemic as well as anti-carcinogenic effects ${ }^{(16)}$. Tannins are also known to possess health benefits, where they are 15 - 30 times more efficient in free radical quenching activity than Trolex and other simple phenolics ${ }^{(17)}$.

The acceptability of legume seed flour depends mainly on the nutritive value as well as functional properties ${ }^{(18)}$. The functional properties of seed flour assume importance in the development of food product. Proteins and starch are the main contributors for changes in functional properties such as Bulk density, oil and water absorption and least gelation concentration. The seeds of Mucuna sloanei possess good functional properties and in vitro protein digestibility ${ }^{(9)}$.

The plant pathogenic fungus Mycosphaerella mucunae is named for being first discovered on Mucuna. Fungal and mycotoxin contamination is also of main concern to minimize the economic losses and reduce the potential health risks to humans and livestock ${ }^{(19)}$. Reports on fungal contamination and mycotoxins of Mucuna seeds are scarce except for a study by Roy, et al ${ }^{(20)}$ who isolated few Aspergilus flaws in Mucuna sloanei seeds, which were capable of reducing aflatoxin $(1.16 \mathrm{mg} / \mathrm{g})$.

Mucuna sloanei is one of the underutilized food crops in Nigeria ${ }^{(4)}$. Most often, Cocoyam and Melon are popularly used in South Eastern Nigeria as a soup thickener. Their high carbohydrate content and oil content respectively could increase ones risk of weight gain. On the other hand, Mucuna sloanei which could be used as a substitute because of its high protein content is most often neglected. Mucuna sloanei seeds are susceptible to fungal and mycotoxin contamination and this posses a potential health risk to human and livestock ${ }^{(19)}$. Presence of stinging hairs is an undesirable agronomic trait of Mucuna plants, which has to be eliminated for ease of domestication of the germ plasma through breeding. Difficulty encountered in processing Mucuna sloanei is also an area of concern. In West African, seeds require cracking, extensive boiling and soaking to eliminate toxic and inhibitory constituents (21). Hydrothermal treatments, fermentation and germination have been shown to be most effective in reducing the anti-nutrients of Mucuna seeds ${ }^{(2)}$. The toxicity on consumption of Mucuna sloanei seeds and their preparations result in dizziness, diarrhea, pathological changes in organs, growth depression and death ${ }^{(22-24)}$.

The aim of this study is to evaluate the effect of different processing methods (Dehulling, Cooking and Fermentation for 24, 48 and 72 hours) on the chemical, functional and microbial properties of Mucuna sloanei seed (Ukpo). Specific objectives were to:

1. Assess the effect of dehulling on the chemical properties (proximate, mineral and anti-nutritional factor), functional properties (least gelation concentration, bulk density, water and oil absorption capacity) and microbial properties (the occurrence of micro-organism) in Mucuna sloanei seeds (Ukpo).

2. Assess the effect of fermentation on the chemical properties (proximate, mineral and anti-nutritional factor), functional properties (least gelation concentration, bulk density, water and oil absorption capacity) and microbial properties (the occurrence of micro-organism) in Mucuna sloanei seeds (Ukpo).

3. Assess the effect of cooking on the chemical properties 
(proximate, mineral and anti-nutritional factor), functional properties (least gelation concentration, bulk density, water and oil absorption capacity) and microbial properties (the occurrence of micro-organism) in Mucuna sloanei seeds (Ukpo).

Adequate information on the chemical composition of Mucuna sloanei is a prerequisite for its effective utilization. Given its remarkable nutritional potential, there is need for nutritional and anti-nutritional factor evaluation as this would form the basis on which it will be constantly utilized as a soup thickener or formulation of new diets or used in the fabrication of new food product in the food industry. Antinutritional factor present in Mucuna sloanei confers come health benefits e.g. the phytic acid of the seeds possesses antioxidant, anti-carcinogenic and hypoglycemic activities ${ }^{(15)}$. This study will help increase knowledge as regarding these benefits. Also, they can impair nutrient utilization e.g. polyphenols decrease digestibility by forming a complex with dietary proteins.

\section{Materials and Methods}

\subsection{Source of Materials}

Mucuna sloanei seeds were purchased at Ogbete Main Market Enugu state Nigeria.

\subsection{Seed Processing}

The purchased Mucuna sloanei seeds were cracked open and divided into 5 parts. One part was dehulled, the other cooked while the other three portions were fermented for 24 hours, 48 hours and 72 hours respectively.

\subsection{Dehulling}

The dehulled seeds were ground and the flour was further divided into 3 portions for chemical, functional and microbial analysis respectively.

\subsection{Cooking}

After cracking, the seeds were cooked for 45 minutes, on cooling, it was ground with a grinder to obtain the flour. The flour was further divided into 3 portions for chemical, functional and microbial analysis respectively.

\subsection{Fermentation}

After cracking, the seeds were fermented in water for 24 hours, 48 hours and 72 hours respectively. Subsequently, the seeds were ground to obtain the seed flour and divided into 3 portions for chemical, functional and microbial analysis respectively.

\subsection{Proximate Composition Analysis}

\subsubsection{Determination of Moisture Content}

Moisture content was determined by the hot oven method ${ }^{(25)}$. One gram of flour was weighed into an aluminum dish of known weight and placed in a hot air oven maintained at $105^{\circ} \mathrm{C}$ over 24 hours. Drying was stopped when a constant weight was achieved after three successive weighing. The samples were cooled in a dessicator and weighed. Moisture content was calculated as percentage loss in weight using the expression:

$$
\text { Percent Moisture Content }(M C)=\frac{Y-X}{Y} \times 100
$$

Where $\mathrm{MC}=$ Moisture content in percent $(\%)$

$\mathrm{Y}=$ Weight of sample before drying

$\mathrm{X}=$ Weight of sample after drying

\subsubsection{Determination of Crude Fat Content}

Fat content was determined by the Soxhlet extraction method ${ }^{(25)}$. One gram of each sample was weighed into filter paper (Whatman No. 2) and put into a dry cellulose thimble, which was then placed in the Soxhlet extraction tube of the unit. Petroleum ether $\left(40^{\circ} \mathrm{C}-60^{\circ} \mathrm{C}\right)$ was poured into the extraction flask to three-quarter full. The samples were refluxed for 6 hours. The extraction was monitored for 6 hours over gentle heat without interruption. After extraction, the solvent was recovered and the flask with the fat was dried at $100^{\circ} \mathrm{C}$ for 10 minutes to vapourize the ether when no odour of ether was evident. The flask was allowed to cool to room temperature in a dessicator and weighed. Drying and weighing continued to constant weight. The percentage fat content was calculated from the differences in weights before and after the extraction.

$$
\text { Crude Fat, } F(\%)=\frac{X 1-X 100 \%}{X 1}
$$

Where: $\mathrm{F}=$ Percent fat content

$\mathrm{X} 1=$ Initial weight of flask and sample

$\mathrm{X} 2=$ Final weight of flask

\subsubsection{Determination of Crude Protein}

This was determined by the Micro-kjeldhl method ${ }^{(25)}$. A $1.0 \mathrm{~g}$ weight of each flour sample was weighed into a $100 \mathrm{ml}$ kjeldahl flask $2.5 \mathrm{~g}$ of anhydrous $\mathrm{Na}_{2} \mathrm{SO}_{4}, 0.5 \mathrm{~g}$ of $\mathrm{CuSO}_{4}$ and $5 \mathrm{ml}$ of concentrated $\mathrm{H}_{2} \mathrm{SO}_{4}$ were added and allowed to stand for $2-3$ hours. The flask was heated in a flame chamber, gently boiled initially for fumes to appear and heated more intensely until the solution was clear. After cooling, the contents were transferred into a $100 \mathrm{ml}$ volumetric flask and made up to the mark with repeated washing using distilled water.

\subsubsection{Determination of Total Ash}

Ash content was determined by AOAC ${ }^{(25)}$ procedure. Two grams of the sample were weighed into a shallow ashing dish (a crucible) that had been ignited, cooled in a desiccators and weighed soon after reaching room temperature. Both the crucible and its content were transferred into muffle furnace which was ignited at $550^{\circ} \mathrm{C}$. Ashing was done for 8 hours, crucible and the ashed sample were removed from the muffle hace, moistened with a few drops of water to expose the unashed carbon, dried in the oven at $100^{\circ} \mathrm{C}$ for 4 hours and re-ashed at $550^{\circ} \mathrm{C}$ for another hours. This was removed from 
muffle furnace, cooled in a dessicator and weighed soon after reaching room temperature.

Percentage ash was calculated using this expression:

$$
\% \text { Ash }=\frac{\text { Weight of Ah X } 100 \%}{\text { Weight of sample used }}
$$

\subsubsection{Determination of Crude Fibre}

Crude fibre was determined by AOAC ${ }^{(25)}$ method. Two grams of the sample was weighed and defatted. The defatted sample was digested with petroleum ether. This was then transferred to a $600 \mathrm{ml}$ beater avoiding fibre contamination from paper or brush. To this, one was added $200 \mathrm{ml}$ boiling $1.25 \% \mathrm{H}_{2} \mathrm{SO}_{4}$ and a few drops of diluted antifoam. The beaker was then placed on the digestion apparatus with preadjusted hot plate and this was allowed to boil for exactly 30 minutes and while boiling, the beaker was rotated periodically to keep solids from adhering to the sides. After boiling, it was filtered using the Buchner funnel. The beaker was then rinsed with $50-75 \mathrm{ml}$ boiling water and washed thoroughly. This was repeated with three $50 \mathrm{ml}$ portions of water and sucked dry. The mat and residue were removed and $200 \mathrm{ml}$ boiling $1.25 \% \mathrm{NaOH}$ was added and boiled for 30 minutes. This was then filtered as above. This was washed with $25 \mathrm{ml}$ boiling $1.25 \% \mathrm{H}_{2} \mathrm{SO}_{4}$, three $50 \mathrm{mls}$ of water and $25 \mathrm{ml}$ alcohol. The mat and residue were then removed and transferred to the Ashing dish. The mat and residue were then dried for two hours at $130^{\circ} \mathrm{C}$, cooled in a dessicator, weighted and ignited at $600^{\circ} \mathrm{C}-150^{\circ} \mathrm{C}$ for 30 minutes. After ignition, the residue were cooled in a dessicator and weighed.

Percent crude fibre was calculated using the expression:

$$
\% \text { Crude Fibre }=\frac{\text { Loss in Weight on Ignition }}{\text { Weight of Food Sample }} \times 100
$$

\subsubsection{Determination of Carbohydrate Content}

The total carbohydrate content was estimated as the difference between 100 and the total sum of moisture, fat, protein, crude fibre and ash.

$$
100-(\% \text { Moisture }+ \text { Protein }+ \text { Fat }+ \text { Ash }+ \text { Fibre })
$$

\subsubsection{Mineral Content Analysis}

The mineral content was determined using the method described by Adeyeye and Adewoke ${ }^{(26)}$. One gram (1g) of dried samples was digested with $25 \mathrm{ml}$ of $0.03 \mathrm{~N}$ hydrochloric acid $(\mathrm{HCl})$. The digest was boiled for 5 minutes, allowed to cool to room temperature and transferred to $50 \mathrm{ml}$ volumetric flask where the volume was made up to the mark. The resulting digest was filtered with ashes Whatman No. 1 filter paper and ready for analysis. The filtrate was analyzed for mineral (calcium, iron, potassium and phosphorus) content using Atomic Absorption Spectophotometer.

\subsubsection{Anti-Nutritional Factor Determination}

Tannin was determined by the modified vanillin method of Price, Hagerman and Butler ${ }^{(27)}$ and phytate was determined by a photometric method adopted from the method of Latta and Eskin ${ }^{(28)}$.

\subsection{Functional Properties}

\subsubsection{Determination of Bulk Density}

Bulk density was determined using the method described by Nwanekezi, et al, ${ }^{(29)}$. The Mucuna sloanei flour was filled into a $100 \mathrm{ml}$ measuring cylinder. The bottom of the cylinder was gently tapped on a laboratory bench until there was no further diminution of the sample after filling to the $100 \mathrm{ml}$ mark. Bulk density was estimated as mass per unit volume of the sample $(\mathrm{g} / \mathrm{ml})$. The mean of triplicate measurement was taken as the estimate of bulk density.

\subsubsection{Determination of Least Gelation Concentration}

The method of Sathe and Salunkhe ${ }^{(30)}$ was adopted. Appropriate sample suspensions of 2, 4, 6, 8, 10, 12, 14, 16, $18,20 \%(\mathrm{w} / \mathrm{v})$ were prepared in $5 \mathrm{ml}$ distilled water. The test tubes containing these suspensions were then heated for one hour in a boiling water bath followed by rapid cooling under running cold tap water. The test tubes were further cooled for 2 hours at $4^{\circ} \mathrm{C}$. The least gelation concentration was determined as that concentration at which the sample from the inverted test tube did not fall down or slip visually.

\subsubsection{Determination of Water Absorption Capacity}

The water absorption capacity was determined by the method of Beuchat ${ }^{(31)}$. One gram of the sample was mixed in $10 \mathrm{ml}$ distilled water for 30 seconds in a mixer. The samples were then allowed to stand at room temperature $\left(25^{\circ} \mathrm{C}\right)$ for 30 minutes and then centrifuged at $5000 \mathrm{x}$ g for 30 minutes and the volume of the supernatant noted in a $10 \mathrm{ml}$ graduated cylinder. Density of water was assumed to be $1.0 \mathrm{~g} / \mathrm{ml}$. The water absorption was expressed as the amount of water retained by $1 \mathrm{~g}$ of flour $(\mathrm{ml} / \mathrm{g})$.

\subsubsection{Determination of Oil Absorption Capacity}

The oil absorption capacity was determined by the method of Beuchat ${ }^{(31)}$. One gram of the sample was mixed with $10 \mathrm{ml}$ of edible vegetable oil for 30 seconds in a mixer. Sample was allowed to stand at room temperature $\left(25^{\circ} \mathrm{C}\right)$ for 30 minutes and then centrifuged at $5000 \mathrm{x} \mathrm{g}$ for 30 minutes and the volume of the supernatant noted in a $10 \mathrm{ml}$ graduated cylinder. Density of oil was assumed to be $0.38 \mathrm{~g} / \mathrm{ml}$. The Oil Absorption was expressed as the amount of oil bound by $1 \mathrm{~g}$ of flour $(\mathrm{ml} / \mathrm{g})$.

\subsubsection{Microbial Analysis}

The Sabouraud Dextrose Agar was prepared as specified in Oxoid ${ }^{(32)}$ manual.

$\begin{array}{ll}\text { Sabouraud Dextrose Agar } \\ \text { Composition: } \\ \text { Nutrient Agar } & 2 \mathrm{~g} \\ \text { Glucose } & 4 \mathrm{~g} \\ \text { Distilled Water } & 100 \mathrm{ml} \\ \text { Chloramphenical } & 1 \text { Capsule }\end{array}$

\subsubsection{Method of Preparation}

Weigh $2 \mathrm{~g}$ of nutrient agar powder and $4 \mathrm{~g}$ of glucose, add one capsule of chloramphenicol, dispense in $100 \mathrm{ml}$ of distilled water, allow to soak for 10 minutes, swirl to mix 
then sterilize by autoclaving for 15 minutes at $121^{\circ} \mathrm{C}$. Cool to $45^{\circ} \mathrm{C}$, mix well then pour into sterilized plates.

\subsubsection{Procedure for Isolation of Micro-Organism from Munuca sloanei Flour}

The sterilized plates were dried in a hot air oven to remove moisture from the surface. The sterile Sabouraud Dextrose Agar (SDA) were poured into the plates and allowed to

solidify. The sterile wire loop was used to collect samples from the test tube and inoculated into the plate containing sabouraud dextrose agar for fungi isolation. The plates were incubated at $37^{\circ} \mathrm{C}$ for $3-5$ days for fungal isolation, after incubation, the plates were observed and results recorded.

\section{Results and Discussion}

Table 1. Functional Properties

\begin{tabular}{llllll}
\hline & Cooked & Dehulled & F24 & F48 & F72 \\
\hline Water Absorption Capacity $(\mathrm{ml} / \mathrm{g})$ & $5.0 \pm 1.00$ & $2.5 \pm 0.15$ & $1.5 \pm 0.17$ & $1.3 \pm 0.10$ & $1.1 \pm 0.10$ \\
Oil Absorption Capacity $(\mathrm{ml} / \mathrm{g})$ & $1.0 \pm 0.10$ & $1.0 \pm 0.10$ & $0.5 \pm 0.20$ & $0.2 \pm 0.10$ \\
Least Gelation Concentration $(\% \mathrm{w} / \mathrm{v})$ & $2 \pm 0.00$ & Trace & $2 \pm 0.00$ & $2 \pm 0.00$ \\
Bulk Density $(\mathrm{g} / \mathrm{ml})$ & $0.40 \pm 0.01$ & $0.57 \pm 0.20$ & $0.59 \pm 0.15$ & $0.61 \pm 0.02$ & 0.01 \\
\hline
\end{tabular}

From table 1, the water absorption capacity of the differently processed samples ranged from $1.1 \mathrm{ml} / \mathrm{g}$ to $5 \mathrm{ml} / \mathrm{g}$. The cooked sample had the highest while the 72 hours fermented sample had the lowest. The result obtained showed the oil absorption capacity of the differently processed ukpo to range between $0.1 \mathrm{ml} / \mathrm{g}-1.0 \mathrm{ml} / \mathrm{g}$. The dehulled and cooked samples had the highest oil absorption capacity while the 72 hour fermentation had the least and it was also observed. The least gelatin concentration of the cooked and fermented samples ( 24 hours, 48 hours, 72 hours) was the same as $2 \% \mathrm{w} / \mathrm{v}$ except the dehulled sample, which had traces of gelation.

From table 2, after 3 days of incubation, no microbial growth was observed in the dehulled sample. Aspergilus $s p$ and Rhizopus were isolated at $37^{\circ} \mathrm{C}$ from the cooked while the fermented samples showed yeast growth of different magnitude.

Table 2. Microbial Properties

\begin{tabular}{lll}
\hline Sample & Organism Isolated & Growth Rate \\
\hline Dehulled & Nil & No growth \\
Cooked & Aspergilus sp and Rhizopus & Moderate \\
24 hrs fermentation & Yeast & Profuse \\
48 hrs fermentation & Yeast & Profuse \\
72 hrs fermentation & Yeast & Moderate \\
\hline
\end{tabular}

Table 3. Proximate Analysis of Cooked, Dehulled and Fermented Mucuna sloanei Seeds

\begin{tabular}{llllll}
\hline & Raw (Dehulled) & Cooked & F24 & F48 & F72 \\
\hline Moisture (\%) & $10.5 \pm 0.20$ & $12.0 \pm 0.20$ & $13.0 \pm 1.00$ & $15.3 \pm 0.22$ \\
Protein (\%) & $24.0 \pm 0.11$ & $19.6 \pm 0.38$ & $28.6 \pm 0.20$ & $33.2 \pm 0.36$ \\
Fat (\%) & $6.5 \pm 0.26$ & $8.3 \pm 0.21$ & $5.9 \pm 0.16$ & $3.8 \pm 0.43$ \\
Fibre (\%) & $3.8 \pm 0.21$ & $5.3 \pm 0.35$ & $3.8 \pm 0.26$ & $3.6 \pm 0.30$ \\
Ash (\%) & $3.3 \pm 0.26$ & $3.0 \pm 0.26$ & $3.5 \pm 0.15$ & $3.9 \pm 0.40$ \\
Carbohydrate (\%) & $54.4 \pm 0.26$ & $62.3 \pm 0.40$ & $45.0 \pm 0.20$ & $37.1 \pm 0.30$ \\
\hline
\end{tabular}

Mean $\pm \mathrm{SD}$ of three replication

As shown by table 3, the moisture content ranged between $10.5 \%-16.0 \%$. The dehulled had the least $10.5 \%$ while the fermented had the highest. The protein content increased from $24.0 \%$ (dehulled) to $35.2 \%$ when fermented decreased to $19.6 \%$ when cooked.

Cooking decreased the Ash content from 3.3\% - 3.0\% while fermentation gradually increased the Ash content. The Ash content increased from $3.3 \%$ to $3.5 \%, 3.3 \%-3.9 \%$ and $3.3 \%-4.2 \%$ after 24,48 and 72 hours fermentation respectively. As the days of fermentation progressed, the fat content decreased cooking on the other hand increased the fat content (from $6.55 \%-8.3 \%$ ). The dehulled sample has a fiber content of $3.8 \%$. Cooking increased the value to $5.3 \%$ while fermentation decreased the value to $3.6 \%$ and $2.9 \%$ for 48 hours and 72 hours respectively. After the first day of fermentation, the value remained unchanged. Cooking increased the carbohydrate content from 54.4\% - $62.3 \%$ while fermentation decreased the value to $45 \%$ (24 hours), $37 \%$ (48 hours) and 32\% (72 hours).

Table 4. Mineral Composition of Processed and Unprocessed Mucuna sloanei Seeds (mg/100g)

\begin{tabular}{llllll}
\hline & Raw (Dehulled) & Cooked & F24 & F48 & F72 \\
\hline Iron & $14.2 \pm 0.30$ & $9.1 \pm 0.10$ & $16.0 \pm 1.00$ & $21.38 \pm 0.20$ \\
Zinc & $4.5 \pm 0.26$ & $3.3 \pm 0.15$ & $5.0 \pm 1.50$ & $7.5 \pm 0.45$ \\
Calcium & $23.6 \pm 0.30$ & $26.0 \pm 1.00$ & $28.9 \pm 0.20$ & $30.0 \pm 0.50$ \\
Phosphorus & $490 \pm 4.4$ & $476 \pm 0.50$ & $498 \pm 1.50$ & 5.17 & $520 \pm 2.00$ \\
\hline
\end{tabular}

Mean $\pm \mathrm{SD}$ of three replication 
As shown in table 4, fermentation increased the mineral content while cooking decreased all but calcium. The iron content increased from $14.2 \%$ (dehulled/unprocessed sample) to $21.30 \%$ after 72 hours of fermentation. Cooking reduced the iron content to $9.1 \%$. There was a continuous increase in the zinc content of the fermented samples, from $4.5 \%$ (dehulled) to $5.0 \%$ (24 hours) $7.5 \%$ (48 hours) and 9.2\% (72 hours) of fermentation respectively. Cooking conversely decreased the zinc content (from $4.5 \%$ in the dehulled to $3.3 \%$ in the cooked).

Cooking increased the calcium content from $23.6 \%-23.0 \%$ but fermentation increased the value better than cooking. As the period of fermentation increased, the calcium content also increased. The phosphorus content ranged from 476\% $526 \%$. As the fermentation period increased, the phosphorus level increased simultaneously but cooking decreased the phosphorus content from $490 \%-476 \%$.

Table 5. Anti-Nutritional Content

\begin{tabular}{llllll}
\hline & Raw (Dehulled) & Cooked & F24 & F48 & F72 \\
\hline Tannin & $28.50 \pm 0.20$ & $15.10 \pm 0.03$ & $24.4 \pm 0.36$ & $22.30 \pm 0.42$ & $17.96 \pm 0.03$ \\
Phytate & $0.46 \pm 0.22$ & $0.08 \pm 0.09$ & $0.44 \pm 0.27$ & $0.43 \pm 0.21$ & $0.38 \pm 0.33$ \\
\hline
\end{tabular}

Mean \pm SD of three replication

From table 5, both cooking and fermentation reduced the tannin and phytate contents of the ukpo. However, cooking reduced the values more than fermentation did. Cooking drastically reduced the tannin content from $28.50 \%$ (dehulled) to $15.10 \%$ while a gradual reduction was observed as the days of fermentation went by. Phytate content ranged from $0.08 \%-0.46 \%$. The cooled sample had the lowest while the dehulled had the highest. Cooking lowered the phytate content better than fermentation did.

\section{Discussion}

\subsection{Proximate Composition}

As shown by table 6 , the moisture content ranged between $10.5 \%-16.0 \%$, the dehulled had the least $10.5 \%$ while the fermented had the highest. The difference in the moisture content is because the fermented ( 72 hours) sample spent longer time in water than the cooked from the cooking reduced the protein content from $24 \%$ in dehulled (raw) to $19.6 \%$ while fermentation increased the raw to $35.2 \%$. The increase in protein content of the fermented sample could be attributed to the hydrolysis of the protein to amino acids and breakdown of tannin protein complex ${ }^{(33)}$. Cooking increased the fat, fiber contents and reduced the ash content while fermentation increased the ash content and reduced the fat and fiber contents. The carbohydrate content of the cooked was high $(62.3 \%)$ while the fermented ( 72 hours) recorded a low value of $35.2 \%$. Hence, cooking increased the carbohydrate content while fermentation decreases it. The decrease could be attributed to conversion of carbohydrates to simple sugars which is further converted to alcohol and carbon dioxide while the increase during cooking could be as a result of starch gelatinization ${ }^{(34)}$.

\subsection{Mineral Composition}

From table 7, fermentation increased the mineral contents (iron, zinc, calcium and phosphorus), cooking decreased except calcium. The result is in line with the report of Enwere ${ }^{(35)}$ which states that fermentation increases the availability of minerals such as calcium and phosphorus through the hydrolysis of phytate and oxalate.

\subsection{Anti-Nutritional Content}

Both cooking and fermentation reduced the tannin and phytate contents of the ukpo as shown by table 8 . However, cooking reduced the values more than fermentation did. This statement is in line with the report of Anglemier and Oguntimien ${ }^{(34)}$ which posits that during cooking, some proteins are denatured, enzymes are inactivated, starch is gelatinized and level of anti-nutrients reduced. Also, Enwere (35) says that some legumes are made edible by extensive hydrolysis of their indigestible components and elimination of nutritional stress factors such as anti-nutritional factors and toxic components through the action of fermenting microorganisms during fermentation. Several anti-nutritional compounds Mucuna serve in health are in a verity of ways. Tannins are known to possess health benefits, wherein they are $15-30$ time more efficient in free radical quenching activity than Trolox and other simple phenolics ${ }^{(17)}$. The phyticacid of Mucuna possesses anti-oxidant, anticarcinogenic and hypoglycemic activities ${ }^{(15)}$

\subsection{Functional Properties}

\subsubsection{Water Absorption Capacity}

Water absorption is the water retained by a protein following filtration and applications of mild pressure of centrifugation force protein vary in their ability to bind and retain water. From table 4, the water absorption capacity of the differently processed samples ranged from $1.1 \mathrm{ml} / \mathrm{g}$ to $5 \mathrm{ml} / \mathrm{g}$. The cooked sample had the highest while the 72 hours fermented sample had the lowest. The difference in their water absorptions may be explained by the processing method they passed through. The high water absorption capacity of the cooked sample could be as a result of protein denaturation by heat while the low water absorption of the 24 hours $(1.5 \mathrm{ml} / \mathrm{g}), 48$ hours $(1.3 \mathrm{ml} / \mathrm{g})$ and 72 hours $(1.1 \mathrm{ml} / \mathrm{g})$ fermented samples would be due to their previous uptake of water during fermentation. The result also showed that as the days of fermentation increased, their water absorption capacities decreased. This report agrees with Lin, et al ${ }^{(36)}$ 
which states that the water absorption capacity is dependent on factors like amount and nature of hydrophilic constituents, denaturation of protein and processing methods. Higher water absorption capacity is important in the thickening effect of soup meaning that the cooked ukpo can absorb larger quality of water than dehulled $(2.5 \mathrm{ml} / \mathrm{g})$ preparation, therefore will give a larger quality of soup than others. This property is also useful in bakery products where hydration to improve handling characteristics is required.

\subsubsection{Oil Absorption Capacity}

Oil absorption is the physical entrapment of oil by the protein molecules. The result obtained showed the oil absorption capacity of the differently processed ukpo to range between $0.1 \mathrm{ml} / \mathrm{g}-1.0 \mathrm{ml} / \mathrm{g}$. The dehulled and cooled samples had the highest oil absorption capacity while the 72 hours fermentation had the least and it was also observed that the oil absorption capacity of the various fermented samples tend to decrease as the days of fermentation increased. The low oil absorption capacity of the fermented samples could be as a result of the absorption of water into the protein molecule of the ukpo during fermentation, thereby having little space for entrapment of oil by the molecule. Its low oil absorption capacity is an advantage because it saves oil and oil/fat acts as flavor retainer and increases the mouth feel of foods ${ }^{(37)}$. Hence, dehulled and cooked ukpo can be utilized in food a system where low oil absorption is deserved, e.g. pancakes, doughnuts, baked goods and soups. But should a very low oil absorption capacity be derived, then ukpo processed by fermentation could be the best option.

\subsubsection{Least Gelation Concentration}

The ability of protein to form gel is important in the structure and texture of many foods ${ }^{(38)}$. As shown by table 4.1 , the least gelation concentration of the cooked and fermented samples ( 24 hours, 48 hours, 72 hours) were the small at $2 \% \mathrm{w} / \mathrm{v}$ except the dehulled sample which had traces of gelation. The difference observed could be as a result of the breakdown of starch into amylase and amylopectin molecules by heat treatment and enzymes during cooking and fermentation respectively while in dehulled, there was no breakdown or rupture of the starch molecules. Similar results were obtained by Kerr et al ${ }^{(39)}$ who states that sorghum, a waxy cereal, had a least gelation concentration of $2 \% \mathrm{w} / \mathrm{v}$ due to the breakdown of starch into high proportion of amylopectin, thereby affecting the gel strengths. In food systems that require thickening and gelling like soup, pudding and sources, cooking and fermentation would be the right processing method for the ukpo.

\subsubsection{Bulk Density}

The result showed that the bulk density ranged between $0.40 \mathrm{~g} / \mathrm{ml}-0.62 \mathrm{~g} / \mathrm{ml}$ with the cooked having the least and the 72 hours fermentation the highest. The dehulled sample had $0.57 \mathrm{~g} / \mathrm{ml}$. From the result, cooking decreased the bulk density whereas fermentation increases it. The increase in the bulk density of the fermented samples could be as a result of uptake of water during fermentation. If food systems where low bulk density is required like in the formulation of complementing foods, cooking would be the most appropriate way of processing while in others where high bulk density is needed then dehulled and fermentation could be the best option.

\subsubsection{Microbial Quality}

The ubiquity of fungi in nature suggests that these organisms may be found on all fresh food products. It is doubtful as to whether one cannot recover yeasts or molds from any raw or fresh food products. The significance of fungi in food, especially molds, stems not only from their spoilage potential but also from the potential of many to produce a variety of mycotoxins to which man is susceptible (40)

\subsubsection{Dehulled Sample}

The dehulled sample had no growth meaning that no fungi was present at that point, this could be as a result of the hard seed coat of the Mucuna sloanei.

\subsubsection{Cooked Sample}

Mold (fungi) can be found virtually everywhere. It can grow on almost any organic substance as long as moisture and oxygen are present ${ }^{(19)}$. The contaminating organisms Aspergillus sp and Rhizopus sp may have entered the seed flour from the environment because they also thrive well in warm and high humid environment or from the processing material as mold spores float through the air on regular basis. This result agrees with that of Roy, et al ${ }^{(20)}$ who isolated five Aspergillus flavus in Mucuna sloanei seeds, which were capable of producing aflatoxin $(1.16 \mathrm{mg} / \mathrm{g})$.

All molds have the potentials to cause adverse health effects. They can produce allergic reactions, breathing problems, or asthma attacks in people allergic to mold. Aspergillus are known for producing aflatoxins which is known to cause cancer in certain animals and is suspected of being the cause of liver cancer in human being living in warm and humid regions of the world where the foods are contaminated by the fungus ${ }^{(40)}$. Due to their chemical nature, aflatoxins are not destroyed by boiling or by any other simple means. Autoclaving for 4 hours has been reported to reduce but not destroy toxicity ${ }^{(40)}$. Observing a high sanitary environmental condition as well as covering the ukpo will help prevent or reduce the risk of contamination during processing.

\subsubsection{Fermentation}

Yeast was the only organism isolated during fermentation. The first and second days of fermentation had profuse growth rate which decrease on the third day (moderate). Lack of fermentable sugars and increase in alcohol and carbondioxide could be the reason for the decrease. Similar results were obtained by James ${ }^{(40)}$ which states that on first day of fermentation of cocoa beans, it consisted of yeasts, and on the third day, the yeast count decreased. It further reported that the cessation of yeast activities around the third day is due in part to lack of fermentable sugars, the increase in 
alcohol and carbondioxide. The yeast might have entered the ukpo from the environment, processing material (utensils) or water. This statement is in line with James ${ }^{(40)}$ who posits that a large number of yeast can be found in the soil and generally low numbers in water. Utensils that are stored in the open where dust might collect should be expected to have airborne bacteria, yeast and molds. Yeasts are common spoilage organisms of foods and grow well in food with high concentration of sugar, salts and low moisture content. They also ferment carbohydrates to produce alcohol and carbondioxide and is important in brewing and bread making. Some yeast is a commercial source of proteins and of vitamins of the B complex. The significance of the yeast is that it causes oral and anal thrust (candidiasis) ${ }^{(40)}$.

\section{Conclusion}

The different processing methods affected the ukpo in different ways. Cooking increased the water and oil absorption capacity and decreased the bulk density while dehulling does not completely support gelation. Fermentation on the other hand increased the bulk density and reduced the water and oil absorption capacity of the ukpo. Dehulling from the standpoint of health can be regarded as a safe method of processing the ukpo as it habours no organism. Some molds were isolated in the cooked while fermentation favoured the growth of yeast.

Fermentation increased the nutritive value as a result of increased digestibility of proteins through their hydrolysis to amino acids, conversion of carbohydrates to simple sugars, thus reducing flatulence. It also increases the availability of minerals through the hydrolysis of anti-nutritional factors. Fermentation increased the protein and ash contents. It also increased the mineral availability and reduced the level of antinutrient while cooking increased the carbohydrate content and fat, fiber decreased the mineral and anti-nutrient contents.

\section{Recommendations}

1. The most appropriate processing method for ukpo depends on what user has in mind. When the functional property is of uttermost concern, then cooking could be the most appropriate, when food safety is desirable, dehulling is the answer. Fermentation improves the nutrient and mineral availability and reduces the antinutrient factor, hence, it is the most appropriate when these parameters are of concern.

2. Fermentation improves the nutritive value, however, heat treatment should be applied after fermentation to reduce or destroy the yeast cells.

3. Meals should be prepared with the fermented sample to determine if fermentation affects the taste, and sensory evaluation should be conducted to determine people's opinion.

4. The rich nutrition potential as well as the good functional properties of this legume should be explored by the food industries for development and formulation of new food products.

5. Ukpo should be used in place of other soup thickeners because of the numerous health benefits, affordability and good functional properties.

6. It can be an effective tool in fighting protein energy malnutrition in children. Hence, ukpo can be used in the formulation of weaning formular because of its high protein content, especially when fermented.

7. Care should be taken during handling and the processing materials/equipment like pot, grinder or mortar and pestle, etc., should be washed and the seed/seed flour should be covered properly to avoid microbial contamination.

8. The result of this study should be implemented through Nutrition Education Programmes and disseminate to various food industries, households, communities and health centres (Antenatal session). This will aid effective utilization of the legume.

\section{References}

[1] Bressani R (2002): Factors influencing nutritive value in food grain legumes Mucuna compared to other grain legumes. In: Food and Feed from Mucuna: current uses and the way forward (Editors, Flores B.M, Ellitta M, Myhrman R, Carew L.B and Carsky), R.J Workshops, CIDICCO, CIEPCA and World Hunger Research Center, Tegucigalpa, Honduras, pp. $164-188$.

[2] Waryekeche E, Wakasa V and Mureithi J.G (2003): Effect of germination alkaline and acid soaking and boiling on the nutritional value of mature and immature Mucuna beans. Tropical and subtropical agroecosystems $(183-192)$.

[3] Diallo O.K, Kante S, Myhrman R, Soumah M. Cisse N.Y and Berhe T (2002): Increasing farmer adoption of Mucuna pruriens as human food and animal feed in the Republic of Guinea. Review of Ecology and Systematic 25:325 - 349.

[4] Afolabi O.A, Oshuntogun B.A, Adewusi S.R, Fapojuwo O.O, Ayorinde F.O, Grisson F.E and Oke O.L (1985): Preliminary nutritional and chemical evaluation of raw seeds from Mucuna sloanei. An underutilized food source. Journal of Agricultural Food Chemistry 38:122 - 124.

[5] Ukachukwu S.N, Ezeagu I.E, Tarawall G and Ikeorgu J.E.G (2002): Utilization of Mucuna as a food and feed from Mucuna. Current uses and the way forward (Editors, Flores B.M, Ellitta M, Myhrman R, Carew L.B and Carsky), R.J Workshops, CIDICCO, CIEPCA and World Hunger Research Center, Tegucigalpa, Honduras, pp. $189-287$.

[6] Haq N (1983): New Food legume crops for the tropics. In: Better crops for food (Editor, Nugent J and Connor M.O), Cuba Foundation Symposium 97, Pitman Books, London. Pp. $144-260$.

[7] Ezueh M.I (1997): Cultivation and utilization of minor food legumes in Nigeria. Tropical Grains Legumes Bulletin No. 10, International Institute for Tropical Agriculture, Ibadan, Nigeria.

[8] Siddhuraju P, Vijayakumari K and Janardhanan k (1996): Chemical composition and protein quality of the little-known legume. Journal of Agricultural Food Chemistry 44:2636 - 2641. 
[9] Adebowale Y.A, Adeyemi I.A and Oshodi A.A (2005): Variability in the physiochemical and anti-nutritional attributes of six Mucuna species. Food Chemistry 89:37 - 48

[10] Iyayi E.A and Egharevba J.I (1998): Biochemical evaluation of seeds of an underutilized legume (Mucuna utilis). Nigeria Journal of Animal Production 25:40 - 45.

[11] FAO (1994): The state of food and agriculture. FAO Series No 27, FAO/UN, Rome.

[12] Michaelsen K.F and Henrik F (1998): Complementary feeding. A Global Perspective. Nutrition 14:763 - 766.

[13] Pelletier D.L (1994): The potentialing effects of malnutrition on child mortality: Epidemiology evidence and policy implications. Nutrition Review 52:409 - 415.

[14] Graf E and Eaton J (1990): Antioxidant function of Phytic. Free Radica, Biology and Medicine 8:61 -69.

[15] Rickard S.W and Thompson L.U (1997): Interactions and biological effects of phytic acid. In: Anti-nutrients and phytochemicals in food (Editor, Dhahidi F). Acs Symposium Series No. 662, American Chemical Society, Washington DC, pp. $294-312$.

[16] Koratkar R and Rao A.V (1997): Effect of soybean saponins on Azoxymethane - induced preneoplatic lessons on the colon of mice nutrition and cancer 27:206 - 209 .

[17] Hurrel R.F, Reddy M and Cook J.D (1999): Inhibition of noniron absorption in man by polyphenolic-containing beverages. British Journal of Nutrition 81:289 - 295. Germinating soybean seeds. Crop Sci. 407 - 415.

[18] Pour-E, A (1981): Protein functionality: classification, definition and methodology. In: Protein functionality in Foods (Editor, Cherry J.P). American Chemical Society Symposium Series No. 147, Washington DC, pp. $1-5$.

[19] Ueno Y (2000): Risk of Multi-exposure to natural toxins. Mycotoxins 50:13 - 22.

[20] Roy A.K, Sinha K.K and Chourasia H.K (1988): Aflatoxin contamination of some common drug plants. Applied and Environmental Microbiology 54:542 - 543 .

[21] Carsky R.J, Tarawali S.A, Becker M. Chikoye D, Tian G and Sanginga N (1998): In Mucuna - Herbaceous cover legume with potential for multiple uses. Resource and Crop Management Research Monograph No. 25, International Institute of Tropical Agriculture Ibadan, Nigeria.

[22] Emenalom O.O and Udebibie A.B.I (1998): Effect of dietary raw cooked and toasted Mucuna pruriens seed (Velvet bean) on the performance of finisher broilers. Nigeria Journal of Animal Production 23: 115 - 119.

[23] Ene-Obong H.N and Carnovale E (1992): Nigeria soup condiments: Traditional processing and potential as dietary fiber source. Food Chemistry 43:29-34.

[24] Hashim Z and Idrus A.Z (1977): Utilization of Lyons Bean (Mucuna cochinchinesis) as feeding stuff. Processings of the feeding stuff for livestock in South East Asia, pp. $154-157$.
[25] A.O.A.C (1995): Official methods of analysis. Association of Official Analytical Chemists, $15^{\text {th }}$ Edition, Washington DC, USA.

[26] Adedeye A and Adewoke K (1992): Chemical composition and fatty acid and profiles of cereals in Nigeria. Food Chem. $44: 41-44$.

[27] Price M.L, Hagerman K.E and Butler L.G (1980): Tannin in sorghum. Effects of cooking on the chemical assay and on anti-nutritional properties in rats. Nutr. Rep. Int. 21:763 - 767.

[28] Latta M and Eskin M (1980): A simple and rapid colorimetric method for phytate determination. J. Agric. Food Chem. 29:13`5-1317.

[29] Nwanekezi E.C, Ohagi N.C and Afam-Anene O.C (2001): Nutritional and organoleptic quality of infant food formulations made from natural and solid state fermented tubers (cassava, sprouted and unsprouted yam) - soybean flour blend. Nig. Fr. J. 19:55 - 62 .

[30] Sathe S.K and Salunkhe D.K (1981): Functional properties of great northern bean (Phaseolus vulgaris L.) proteins: emulsion, foaming and gelation properties. J. Food Sci. $74-77$.

[31] Beuchat L.R (1977): Functional and electrophoresis characteristics of succinylated peanut flour proteins. J. Ag. Fd. Chem. 25:258-260.

[32] Oxoid (1982). The Oxoid manual of culture media, ingredients and other laboratory services. Basingstoke, Hampshire: Oxoid Ltd., 1982.

[33] Chen L.H and Thracker R.R (1978): Germination and nitrogenous constitutents of pea sees (Pisium sativuum). J. Food Sci. 46:1884 - 1885.

[34] Anglemier H.R and Oguntimein G.B (1993): Exploitation of indigenous technology in the beverage industry. Paper presented at the $17^{\text {th }}$ Annual Conference of the Nigerian Institute of Food Science and Technology, Ilorin, Dec., 6 - 10, 1993.

[35] Enwere N.J (1998): Food of Plan Origin - Afro-Orbis Publishers Ltd., Nigeria. Pp. 24 - 130.

[36] Lin M.J.Y, Humbert E.S and Sosulski F.W (1979): Certain functional properties of sunflower meal projects. J. Food Sci. 29:368.

[37] Eke O.S and Akobundu E.N.T (1993): Functional properties of African yam bean (Sphenostyles stenocarpa) seed flour as affected by processing. Food Chem. 48:337 - 340 .

[38] Schmidt R.H (1981) Gelation and Coagulation. ACS Symp. Ser. 147:131 - 148

[39] Kerr W.L, Ward C.D.W, McWatters K.H and Resurrection A.V.A (2000): Milling and particle size of cowpea flour and snack chip quality. Food Research International 34:39 - 45.

[40] James M.J (1978): Modern food microbiology, Second edition. Van Nostrand Keinhold Company, New York, pp. 12 - 404. 